\title{
Enzyme-linked Immunosorbent Assay (ELISA) as a Means of Taxonomic Analysis of Streptomyces and Related Organisms
}

\author{
By R. KIRBY* AND E. P. RYBICKI \\ Department of Microbiology, University of Cape Town, Rondebosch 7700, South Africa
}

(Received 2 December 1985 ; revised 19 February 1986)

\begin{abstract}
Fourteen Streptomyces strains from various numerical taxonomic classes and representatives of three other genera of actinomycetes were studied using an indirect enzyme-linked immunosorbent assay (IND-ELISA) to determine their serological relationships. The INDELISA results agreed with those from previous numerical taxonomic analyses and Ouchterlony double-diffusion studies. The IND-ELISA method is quicker, more quantitative and less subjective than Ouchterlony assays and thus should be useful in Streptomyces taxonomy. The results indicated that Frankia sp. CpIl was related to Streptomyces.
\end{abstract}

\section{INTRODUCTION}

Three major approaches have been used to study the taxonomy of Streptomyces: morphology and pigment production, numerical taxonomy and nucleic acid hybridization. Identification of Streptomyces has generally relied on morphology and pigment production. This is subjective in many cases, especially where there is variation in the growth media used and the point in the growth cycle that examination takes place. Numerical taxonomy is more reliable as it uses a wide variety of criteria, but much work is needed to create a comprehensive data base. Nucleic acid hybridization (DNA-RNA or DNA-DNA) requires the use of radiochemicals, the careful preparation of nucleic acid and a high degree of control of hybridization conditions (Mordarski et al., 1981). In a few cases, serology has been used to study the taxonomy of Streptomyces and related species with some success (Ridell, 1981; Ridell \& Williams, 1983).

Serological techniques allow direct study of the proteins produced by the various Streptomyces and therefore should allow quantification of the divergence of these proteins between species. In previous studies using serological techniques, Ouchterlony double-diffusion assays have been used to measure the major protein similarities of Streptomyces species (Ridell \& Williams, 1983). This approach has three disadvantages. Firstly, only the major soluble antigens can be studied and any minor components are ignored. Secondly, the assay is semiquantitative as only the number of major antigens detected is counted and not their degree of cross-reaction. Finally, the identification of precipitin lines and spurs is subjective and difficult to reproduce in a reaction involving a very complex antigen mixture such as that from total soluble bacterial cell contents. Moreover, the Ouchterlony technique is far less sensitive than indirect enzyme-linked immunosorbent assay (IND-ELISA), which has the added advantage of being usable for membrane bound or insoluble antigens as well as for soluble ones.

IND-ELISA involves the coating of the plastic wells of an ELISA plate with the antigen to be tested, the binding of a known antibody to its specific antigen in the coated well and then detection of the binding by an enzyme-linked second antibody and a specific substrate reaction. The result is a direct quantitative analysis of the amount of antibody bound to the coated antigen. In this study we investigate the potential of IND-ELISA as a taxonomic tool.

Abbreviation: IND-ELISA, Indirect enzyme-linked immunosorbent assay. 


\section{METHODS}

Test strains. The strains used are described in Table 1 . These represent 11 clusters as defined by Williams et al. (1983). A strain of Agrobacterium tumefaciens was included as a control to measure non-specific antibody binding. It was chosen as a soil bacterium of distant taxonomic relatedness.

Antigen preparation. The strains were inoculated into $100 \mathrm{ml}$ Malt-3 liquid medium (Kirby \& Lewis, 1981) and incubated for $3-5 \mathrm{~d}$ at $30^{\circ} \mathrm{C}$ on a rotary shaker, The cells were harvested by centrifugation at $10000 \mathrm{~g}$ in a Sorvall GSA rotor for $15 \mathrm{~min}$. The pellet was washed twice with $0.1 \mathrm{M}$-sodium phosphate, $0.15 \mathrm{M}$-sodium chloride, $\mathrm{pH} 7.4$ (PBS), then sonicated using an MSE Soniprep 150 fitted with a microprobe. This was done on ice for a total of $2 \mathrm{~min}$ in $20 \mathrm{~s}$ bursts with $20 \mathrm{~s}$ gaps for cooling. The procedure effectively disrupted most of the bacteria. The sonicate was filtered through a $0.4 \mu \mathrm{m}$ Millex low binding filter. Protein in the sample was measured by the Lowry method and diluted to $1 \mathrm{mg} \mathrm{ml}^{-1}$ in $20 \%(\mathrm{v} / \mathrm{v})$ glycerol and frozen at $-70^{\circ} \mathrm{C}$.

Antisera preparation. Antisera were prepared for Streptomyces griseus and Streptomyces cattleya. Antigen suspensions $\left(10 \mathrm{mg}\right.$ protein $\mathrm{ml}^{-1}$ were emulsified as a mixture 1:1 (v/v) with Freund's incomplete adjuvant and $1 \mathrm{ml}$ was injected into a rabbit's thigh muscle at 3 week intervals. Blood $(20 \mathrm{ml})$ was taken at weekly intervals from the marginal ear vein starting 3 weeks after the beginning of the course of injections.

IND-ELISA. Polystyrene microtitre plates (Greiner) were coated with twofold dilutions of the antigen samples in PBS, for $2 \mathrm{~h}$ at $37^{\circ} \mathrm{C}$, starting with a standardized protein concentration of $1 \mathrm{mg} \mathrm{ml}^{-1}$. In all tests, antigens from Streptomyces griseus ISP 5236, Streptomyces cattleya C2201, Frankia sp. CpI1, Streptoverticillium griseocarneum ATCC 12628, Rhodococcus corallinus and Agrobacterium tumefaciens were included as controls. The plates were washed by soaking for $5 \mathrm{~min}$ in three changes of PBS $+0.05 \%(\mathrm{v} / \mathrm{v})$ Tween 20 , and blocked with PBS/Tween $+0.5 \%(\mathrm{w} / \mathrm{v})$ bovine serum albumin (Sigma) for $2 \mathrm{~h}$ at $37^{\circ} \mathrm{C}$. The plates were filled with a $1: 100$ dilution of the appropriate antiserum in PBS/Tween/BSA for $1 \mathrm{~h}$ at $37^{\circ} \mathrm{C}$. After washing, goat anti-rabbit antibody conjugated to alkaline phosphatase $\left(1 \mathrm{mg}\right.$ antibody $\mathrm{ml}^{-1} ;$ Miles Yeda) was added to the wells at a dilution of $1: 1000$ and incubated for $1 \mathrm{~h}$ at $37^{\circ} \mathrm{C}$. The alkaline phosphatase bound in the microtitre wells was assayed with $1 \mathrm{mg} p$-nitrophenyl phosphate $\mathrm{ml}^{-1}$ (Sigma) in $10 \%(\mathrm{w} / \mathrm{v})$ diethanolamine, $\mathrm{pH}$ 9.8. The $p$-nitrophenol released was measured after $1 \mathrm{~h}$ at $405 \mathrm{~nm}$ on a Titertek Multiskan microtitre plate reader (Flow Laboratories) relative to the lane containing the dilution series of the control $A$. tumefaciens protein. Absorbance data were first standardized by taking the homologous absorbance reaction value as indicating $100 \%$ similarity and the $\mathrm{Agrobacterium}$ antigen absorbance as indicating $0 \%$ similarity. The standardized data from individual plates could then be directly compared as a percentage of the homologous reaction and this was taken as the similarity using this ELISA system.

\section{RESULTS AND DISCUSSION}

$S$. griseus, $S$. cattleya, Frankia sp. CpI1, Stv. griseocarneum and $R$. corallinus were included in all ELISA plates. In all cases, the duplicate readings for each of these species were within $6 \%$ of the mean for each species with a given antiserum. As the protein concentration of all samples was standardized, the reading obtained between plates was consistent throughout all the samples tested. Table 1 shows the similarity of the strains tested by ELISA using the antisera obtained to the reference strains. No cross-reaction was obtained with the $A$. tumefaciens protein, and $R$. corallinus gave a consistently low reaction of $<10 \%$. Therefore, the level of response obtained with the ELISA with any given species measures the specific common antigens present in the test strain and the reference strain. A consistent series of decreasing similarities were obtained, which correlated with other classifications of these strains.

Classification of Streptomyces by numerical taxonomy places most of the strains tested in different clusters. The $S_{S M} /$ UPGMA value ranges of the test strains compared to the mean INDELISA similarities were as follows: the $>81 \% S_{S M} /$ UPGMA range had a mean IND-ELISA similarity of $79 \%$; the $<81 \%$ to $>77.5 \%$ range had a mean similarity of $71 \%$; the $<77.5 \%$ to $>70.1 \%$ range had a mean similarity of $43 \%$; while the $<70.5 \%$ range had a mean similarity of $34 \%$. There was a strong correlation between the two systems, supporting the conclusions of Ridell \& Williams (1983), who used Ouchterlony double diffusion assays. However, the INDELISA test is rapid and can be easily mechanised, and should prove to be a more reliable and reproducible system for such studies. The results for $S$. rimosus in the IND-ELISA tests agree with the distinctness of the $S$. rimosus cluster as emphasized by Williams et al. (1983) and Alderson et al. (1985).

Both Stv. griseocarneum and Frankia sp. CpIl showed a distinctly higher similarity to $S$. griseus and $S$. cattleya than did $R$. corallinus. This might be expected as $R$. corallinus has almost 
Table 1. Bacterial strains and properties

Species $\begin{aligned} & \text { Cluster Cluster } \\ & \text { group no.* }\end{aligned}$ Strain no. ${ }^{*} \begin{gathered}\text { Antibiotic } \\ \text { produced }\end{gathered}$

Streptomyces griseus

S. bikiniensis

S. alboniger

$S$. halstedii

S. olivaceus

'S. fulvoviridis'

S. venezuelae

S. lipmanii

S. aureofaciens

$S$. chartreusis

'S. lividans'

S. hygroscopicus

$S$. rimosus

S. cattleya

Streptoverticillium

griseocarneum

Frankia sp.

Rhodococcus corallinus§

Agrobacterium tumefaciens

\begin{tabular}{|c|c|c|c|}
\hline A & $1 \mathrm{~B}$ & ISP 5236 & Streptomycin \\
\hline$A$ & 1B & ISP 5235 & Streptomycin \\
\hline A & 1B & ISP 5043 & Puromycin \\
\hline A & $1 \mathrm{C}$ & ATCC 10897 & - \\
\hline A & $1 \mathrm{C}$ & ATCC 3335 & $\beta$-Lactam \\
\hline A & 3 & ATCC 15863 & $\beta$-Lactam \\
\hline A & 6 & ATCC 10712 & Chloramphenicol \\
\hline $\mathbf{A}$ & 7 & C1940 & $\beta$-Lactam \\
\hline A & 14 & ATCC 10762 & $\beta$-Lactam \\
\hline A & 18 & ATCC 14922 & $\beta$-Lactam \\
\hline A & 21 & ISP 5434 & - \\
\hline $\mathbf{A}$ & 32 & ATCC 31039 & $\beta$-Lactam \\
\hline B & 42 & ATCC 10970 & Tetracycline \\
\hline C & 47 & $\mathrm{C} 2201$ & $\beta$-Lactam \\
\hline $\mathrm{F}$ & 55 & ATCC 12628 & $\begin{array}{l}\text { Hydroxy- } \\
\text { streptomycin }\end{array}$ \\
\hline & NA & CpIl & - \\
\hline & NA & UCT & - \\
\hline
\end{tabular}

Percentage similarity to: $\ddagger$

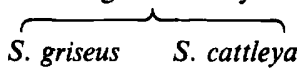

$\begin{array}{cc}100 & 35 \pm 2 \\ 83 \pm 5 & 34 \pm 3 \\ 75 \pm 5 & 33 \pm 4 \\ 73 \pm 3 & 37 \pm 6 \\ 69 \pm 4 & 56 \pm 5 \\ 42 \pm 4 & 39 \pm 5 \\ 57 \pm 3 & 33 \pm 3 \\ 30 \pm 5 & 28 \pm 5 \\ 54 \pm 5 & 20 \pm 3 \\ 38 \pm 3 & 27 \pm 4 \\ 45 \pm 5 & 78 \pm 4 \\ 59 \pm 4 & 27 \pm 4 \\ 27 \pm 4 & 45 \pm 5 \\ 35 \pm 2 & 100 \\ 41 \pm 4 & 31 \pm 3 \\ 27 \pm 2 & 29 \pm 2 \\ 7 \pm 2 & 9 \pm 2 \\ 0 & 0\end{array}$

NA, Not applicable.

* According to Williams et al. (1983), except for $S$. hygroscopicus, which was not the strain they used.

† ISP, International Streptomyces Project; UCT, University of Cape Town stock collection; C1940 and C2201 kindly provided by Glaxo Research.

$\ddagger$ The similarities to $S$. griseus and $S$. cattleya were measured by IND-ELISA using antiserum to these species and an $\boldsymbol{A}$. tumefaciens control as described in Methods. The results are means of 3 determinations \pm SD.

$\S$ Nocardia corallina of Kirby \& Usdin (1985).

no mycelial development and would thus seem to differ from the other strains tested, which have highly developed mycelia. Stv. griseocarneum is classified within the main group of Streptomyces by IND-ELISA although with both antisera it showed a similarity approaching that of the least similar Streptomyces species. Ridell \& Williams (1983) found that the two species of Streptoverticillium tested had two precipitin lines in common with a number of Streptomyces species. Thus both techniques indicate that the genera Streptomyces and Streptoverticillium are related but distinct (Williams et al., 1985).

Frankia sp. CpIl was included in this study because little is known about the taxonomy of this genus, and it was hoped that IND-ELISA might facilitate the study of the relatedness of Frankia spp. directly in their symbiotic nodules without the need to grow the organism in pure culture (Becking, 1981). The IND-ELISA results showed that Frankia sp. CpIl could be classified within Streptomyces. However, the similarity was only $27-29 \%$ with the test antisera and below that of Stv. griseocarneum. Antiserum raised to Frankia sp. CpI1 showed a $62 \%$ similarity with S. griseus ISP 5236, 45\% similarity with Micromonospora chalcea ATCC $12452,37 \%$ similarity with Stv. griseocarneum ATCC 12628 and $6 \%$ similarity with $R$. corallinus. This suggests that this species is closely related to Streptomyces but nevertheless is a member of a distinct genus.

A number of the strains used produce $\beta$-lactam-type antibiotics. It is interesting that no correlation was obtained between the $\beta$-lactam-producing Streptomyces studied using the antiserum to $S$. cattleya, even though this species was taxonomically distinct from most of the strains tested. Thus, the majority of antigens in common between $\beta$-lactam-producing Streptomyces must relate to their being Streptomyces, only a minor proportion being due to proteins related to $\beta$-lactam production. Therefore, the direct application of IND-ELISA with antibodies to whole cell extracts as a screening method for novel $\beta$-lactam producers is not feasible.

The authors would like to acknowledge support of the Council for Scientific and Industrial Research for funding this work and Professor M. B. von Wechmar and Eric O'Neill for their help in providing antisera. 


\section{REFERENCES}

Alderson, G., GoOdfellow, M. \& Minnikin, D. E. (1985). Menaquinone composition in the classification of Streptomyces and other sporoactinomycetes. Journal of General Microbiology 131, 1671-1679.

Becking, J.-H. (1983). The genus Frankia. In The Prokaryotes, pp. 1991-2003. Edited by M. P. Starr, H. Stolp, H. G. Trüper, A. Balows \& G. Schegel. Berlin, Heidelberg \& New York: Springer-Verlag.

KIRBY, R. \& LEWIS, E. (1981). Unstable genetic elements affecting streptomycin resistance in the streptomycin-producing organisms Streptomyces griseus NCIB 8506 and Streptomyces bikiniensis ISP 5235. Journal of General Microbiology 122, 351355.

KIRBY, R. \& UsDIN, K. (1985). The isolation and restriction mapping of a miniplasmid from the actinomycete Nocardia corallina. FEMS Microbiology Letters 27, 57-59.

Mordarski, M., TKaCZ, A., Goodfellow, M., Schaal, K. P. \& Pulverer, G. (1981). Ribosomal ribonucleic acid similarities in the classification of

Actinomycetes. In Actinomycetes, pp. 79-85. Edited by K. P. Schaal \& G. Pulverer. Stuttgart \& New York: Gustav Fischer Verlag.

RIDELL, M. (1981). Immunodiffusion studies of Mycobacterium, Nocardia and Rhodococcus for taxonomic purposes. In Actinomycetes, pp. 235-241. Edited by K. P. Schaal \& G. Pulverer. Stuttgart \& New York: Gustav Fischer Verlag.

RIDELL, M. \& Williams, S. T. (1983). Serotaxonomical analyses of some Streptomyces and related organisms. Journal of General Microbiology 129, 28572861.

Williams, S. T., Goodfellow, M., Alderson, G., Wellington, E. M. H., SNeath, P. H. A. \& Sackin, M. J. (1983). Numerical classification of Streptomyces and related genera. Journal of General Microbiology 129, 1743-1813.

Williams, S. T., LocCi, R., Vickers, J., Schofield, G. M., SNeAth, P. H. A. \& Mortimer, A. M. (1985). Probabilistic identification of Streptoverticillium species. Journal of General Microbiology 131, 1681-1689. 